Sains Malaysiana 47(6)(2018): 1285-1291

http://dx.doi.org/10.17576/jsm-2018-4706-25

\title{
The Effects of Maleic Anhydride Grafted PP (MAPP) on the Mechanical Properties of Injection Moulded Kenaf/CNTs/PP Composites
}

(Kesan Maleik Anhidrida Disaluti PP ke atas Sifat Mekanik bagi Pengacuan Suntikan Komposit Kenaf/CNT/PP)

ZaKaria RaZaK, Abu BaKar SulonG*, Norhamidi Muhamad, Che HaSSAn Che Haron, Mohd Khairol Fadzly MD RADZI, DULINA THOLIBON, IZDIHAR THARAZI \& NUR FARHANI ISMAIL

\section{ABSTRACT}

Composite materials have increasingly become crucial in manufacturing engineering products and producing commodity materials in the major industries including; automotive, aerospace, marine, construction, agriculture and health science. However, several improvements regarding the strength, dimensional stability and the cost of production are required. In this study, composite of Kenaf, multi-wall carbon nanotube (MWCNT) and polypropylene (PP) with maleic anhydridegrafted polypropylene (MAPP) are examined. The results highlight that increasing MAPP loading, in turn, increases the value of the mechanical properties. The composites are produced by blending kenaf/MWCNT/PP using a Sigma blade mixer and injection moulding. Injection moulding is a significant operation used to produce plastic products. In the study, Kenaf core fibre was mixed with MWCNT and polypropylene, in addition to MAPP. The MAPP is added by applying different percentage $(1,2,3$ and $4 \mathrm{wt}$. \%) during the blending process. The main objective of the study was to analyse the effects of MAPP concentrations on the mechanical properties of the Kenaf/MWCNT/PP composite. The results of the study established that MAPP 3 wt. \% concentration with MWCNT 3 wt. \% loading and Kenaf 30 wt. \% filler provide optimum results for the composites. There was approximately, a $21 \%$ enhance in tensile strength of Kenaf $30 \mathrm{wt}$. \%/MWCNT, $3 \mathrm{wt}$. $\% / M A P P, 3 w t . \% / P P$ observed compared to the (without) MAPP composite. The composites with coupling agent stimulate better filler dispersion between Kenaf, MWCNT and PP observed using a scanning electron microscope (SEM) and fieldemission scanning electron microscope (FESEM).

Keywords: Carbon nanotubes; compatibilizer; injection moulding; mechanical properties; natural fibres

ABSTRAK

Bahan komposit menjadi semakin penting dalam pembuatan produk kejuruteraan dan menghasilkan bahan-bahan komoditi dalam industri utama termasuk; automotif, aeroangkasa, marin, pembinaan, pertanian dan sains kesihatan. Walau bagaimanapun, beberapa penambahbaikan mengenai kekuatan, kestabilan dimensi dan kos pengeluaran diperlukan. Dalam kajian ini, komposit kenaf, karbon nanotiub pelbagai dinding (MWCNT) dan polipropilena (PP) dengan maleat anhidrida disaluti PP (MAPP) dikaji. Keputusan menunjukkan bahawa peningkatan beban MAPP, pada gilirannya, meningkatkan nilai sifat mekanik. Komposit dihasilkan dengan penggabungan PP/MWCNT/Kenaf menggunakan pencampur bilah Sigma dan pengacuan suntikan. Pengacuan suntikan adalah operasi penting yang digunakan untuk menghasilkan produk plastik. Dalam kajian ini, serat teras kenaf telah dicampur dengan MWCNT dan polipropilena, sebagai tambahan kepada MAPP. MAPP ditambah dengan menggunakan peratusan yang berlainan (1, 2, 3 dan $4 \%$ bt.) semasa proses pengadunan. Objektif utama kajian ini adalah untuk menganalisis kesan kepekatan MAPP terhadap sifat mekanik komposit PP/MWCNT/Kenaf. Keputusan kajian mendapati bahawa kepekatan $3 \%$ bt. MAPP dengan beban $3 \%$ bt. MWCNT dan pengisi $30 \%$ bt. kenaf memberikan hasil optimum untuk komposit. Terdapat kira-kira $21 \%$ peningkatan dalam kekuatan tegangan pada PP/ $3 \%$ bt. MAPP/ $3 \%$ bt. MWCNT/ $30 \%$ bt. Kenaf telah diperhatikan berbanding dengan (tanpa) komposit MAPP. Komposit dengan ejen gandingan merangsang penyebaran pengisi yang lebih baik antara Kenaf, MWCNT dan PP yang diamati dengan menggunakan mikroskop elektron pengimbas (SEM) dan mikroskop elektron pengimbas pelepasan medan (FESEM).

Kata kunci: Acuan suntikan; gentian semula jadi; karbon nanotiub; pengserasi; sifat mekanik

\section{INTRODUCTION}

Researchers over the years have conducted numerous studies to improve polymer composites due to environmental concerns and material properties. With the emergence of modern technologies, to enhance the production and use of materials in many industries has proven to be economical viable and environmentally encouraging. Many researchers have created innovative ideas and suggestions to meet material property requirements for a myriad of applications in industries including automotive, aerospace, marine, construction, agriculture and health science. The requirement for new and environmentally 
safe materials is a primary focus area globally, gaining significant attention, given the technical and ecological concerns. In 1991, Iijima discovered Carbon Nanotubes (CNTs) which exhibit high performance in thermal conditions, mechanical properties, chemical stability and electrical conductivity (Iijima 1991; Lee et al. 2009). The application of CNTs has been investigated as potential filler for polymer nanocomposites. These include; polypeopyene (PP), polymethyl methacrylate (PMMA), polyethylene (PE), polyamide, used to improve rheological, mechanical, electrical and thermal properties (Farzi et al. 2009; Kim et al. 2010). Sulong and Park (2010) confirmed the increase in mechanical properties by adding CNTs to pure polymer.

MAPP can also be applied to enhance the compatibility between matrix and filler (Lu \& Harold 2005). Schneider et al. (1995) identified that the MAPP could enhance the mechanical properties of the composites obtained from kenaf and jute reinforced PP. Karmaker et al. (1996) reported that the mechanical properties increased by adding MAPP to jute and PP. Kenaf as a natural fibre is recognised and applied as a primary fibre used for composite and engineering applications. Kenaf fibre has the potential to be used as reinforced fibre for thermosets and thermoplastic composites. However, changes to the fibre are required to enhance the mechanical properties of the composite product (Edeerozey et al. 2007; Karnani et al. 1997; Sharifah \& Martin 2004; Sharifah et al. 2005). Kenaf particles with sound reinforcement would enhance the mechanical properties of composites thereby improving the loading of kenaf particles (MdRadzi 2015).

Polymer composites received increasing interest because of the comparatively straightforward process to produce new materials having balanced properties. Polypropylene, as an inexpensive material, offers a combination of existing physical, mechanical, thermal, chemical and electrical properties as compared to other thermoplastic materials. Additionally, compared with low or high-density polyethylene, it performs better under various operational temperature conditions, has greater tensile strength, but with lower impact strength. Polypropylene is one many crucial commodity polymers applied to household appliances, automobile, marine and commercial products due to inherent stable mechanical properties.

\section{MATERIALS AND METHODS}

Polypropylene impact copolymer automotive grade SM850 (melt index $45 \mathrm{~g} / 10 \mathrm{~min}$, density $0.9 \mathrm{~g} / \mathrm{cm}^{3}$ ) was supplied from Lotte Chemical Titan (M) Sdn. Bhd. The MWCNTs were supplied from Nanocyl SA (Belgium) with an average diameter $(9.5 \mathrm{~mm})$ length $(1.5 \mu \mathrm{m})$ and purity $(90 \%)$ of the tubes. The surface area of MWCNT was $250-300 \mathrm{~m}^{2} / \mathrm{g}$ and with a volume resistivity of 10-4 $\Omega . \mathrm{cm}$. Kenaf core particles, size 20 mesh, were supplied from the National Kenaf and Tobacco Board and MAPP were obtained from Sigma-Aldrich.
In this study, the feedstock was composed PP, kenaf, MWCNT along with different percentage of MAPP. The feedstock was cut using a crusher machine. The compounding of the polypropylene, kenaf, MWCNT and MAPP was carried out using a sigma blade mixer at $190^{\circ} \mathrm{C}$ for $0.5 \mathrm{~h}$ and with a rotor speed of 45 RPM. Table 1 lists the materials used in the study, where the MWCNT 3 wt. \% is selected due to contributing good mechanical properties as mentioned by Razak et al. (2016).

TABLE 1 . The percentage of materials used in the study

\begin{tabular}{cccc}
\hline $\begin{array}{c}\text { PP } \\
\text { (wt. \%) }\end{array}$ & $\begin{array}{c}\text { Kenaf } \\
\text { (wt. \%) }\end{array}$ & $\begin{array}{c}\text { MWCNT } \\
\text { (wt. \%) }\end{array}$ & $\begin{array}{c}\text { MAPP } \\
\text { (wt. \%) }\end{array}$ \\
\hline 100 & 0 & 0 & 0 \\
70 & 30 & 0 & 0 \\
66 & 30 & 3 & 1 \\
65 & 30 & 3 & 2 \\
64 & 30 & 3 & 3 \\
63 & 30 & 3 & 4 \\
\hline
\end{tabular}

A Battenfeld injection moulding machine type BA250CDC was used to produce the composites of the specimens in this study. The specimens were created, (including dimensions) based on the ASTM Standard. The tensile, flexural and Izod impact of composites were examined under ambient room temperature $\left(25^{\circ} \mathrm{C}\right)$ with the average values of the five specimens recorded. A universal testing machine (Instron 5567) was used to conduct tensile (ASTM D638) and flexural (ASTM D790) testing until failure occurred. The three-point bend method was utilised for the flexural test. During the tension test, a cross-head speed (2 $\mathrm{mm} / \mathrm{min}$ ) and support span $(43 \mathrm{~mm})$ with a load cell of $1 \mathrm{kN}$ were used for each experiment until failure occurred. The Notched Izod impact strength (ASTM D256) was tested on a Victor Impact Pendulum Tester using a 1 Joule hammer. For all specimens tested, five measurements were averaged and recorded. The thermograms of Kenaf/MWCNT/MAPP/ PP composite were recorded using a TA Instrument (Model Q500) using a temperature range of $0-600^{\circ} \mathrm{C}$.

Injection moulding samples were scanned applying electron microscopy (SEM) to analyse the surfaces fracture of the tensile and impact specimens with and without MAPP using a Hitachi TM-1000 scanning electron microscope.

\section{RESULTS AND DISCUSSION}

\section{TENSILE PROPERTIES}

Figure 1 shows the experimental results of the tensile strength and Young's modulus of Kenaf/MWCNT/PP composites with MAPP and without MAPP. The tensile strength of PP was 18.63 MPa, and with the addition of kenaf 30 wt. \% PP, this reduced the tensile strength of the Kenaf/ PP composites became 15.91 MPa resulting in a reduction 
of $14.6 \%$ compared to PP. The addition of MWCNT 3 wt. $\%$ on the Kenaf/PP composite was $23.45 \mathrm{MPa}$, resulting in the tensile strength increasing by $25.9 \%$ compared to PP. The addition of MAPP 3 wt. \% showed the highest value for the tensile strength of the composites indicating that this can be applied as a coupling agent. This also resulted in an improvement of $52.76 \%$ compared to PP, $78.87 \%$ compared to Kenaf 30 wt. $\% / \mathrm{PP}$ and $21.36 \%$ as compared to Kenaf 30 wt. \%/MWCNT 3 wt. \%/PP due to the amalgamation of MAPP. Additionally, this improved the tensile strength of the composites due to better compatibility at interfacial areas amid the filler and matrix (Amran et al. 2014). Saad (2011) reported excellent dispersion of the filler-matrix resulting from the formation of the anhydride groups of epolene 43 occurring between an ester bond at the surfaces of Kenaf filler. The reduction of the tensile strength at MAPP 4 wt. \% also caused additional stress points from the matrix of fibre (Rozman et al. 2001). The addition of fillers obtained comparable results, thereby decreasing the tensile strength of the composites without a coupling (Eng et al.2014). Figure 1(b) illustrates the effect of MAPP on Young's modulus of Kenaf/MWCNT/PP composites. The result showed that Young's modulus of composites improved with the increasing of MAPP loading and observed in the relative stiffness of the composites. The change of Young's modulus is predominantly due to several factors, such as the orientation of the fillers, the amount of filler used and the adhesion between the matrix and the ratio of filler to the matrix (Huseinsyah et al. 2016).

\section{FLEXURAL PROPERTIES}

Figure 2 illustrates the effect of MAPP on the flexural modulus and strength of Kenaf/MWCNT/PP composites. The results showed the composites being positively affected increasing filler loading. The flexural modulus and strength were both improved with the addition of MAPP $3 \mathrm{wt}$. \% clearly showing that the highest properties of the composites slightly decreased by 4 wt. \%. This observation was expected because, under normal conditions, the addition of fillers will increase the modulus of material. The modulus of flexural for the four mineral fillers (calcium carbonate, clay, mica and talcum powder) increased the aspect ratio with the addition of filler particles (Riley et al. 1990). Equivalent results were obtained for epoxy nanocomposites reinforced with hybrid fibre carbon nanotube and nano clay (Mohd Hafizuddin et al. 2016).

Figure 3 illustrates the effect of Kenaf/MWCNT/PP with the addition of MAPP on the impact strength. The addition of MAPP 3 wt. \% increases the impact strength and slightly declined by $4 \mathrm{wt} . \%$. The impact strength of the composite is a measure of the materials ability to resist fracture due to the pressure caused at high speed where the resulting value shows the toughness of the material influenced by the strength of the bond interphase, the nature of the matrix and filler (Panthapulakkal \& Sain 2007).
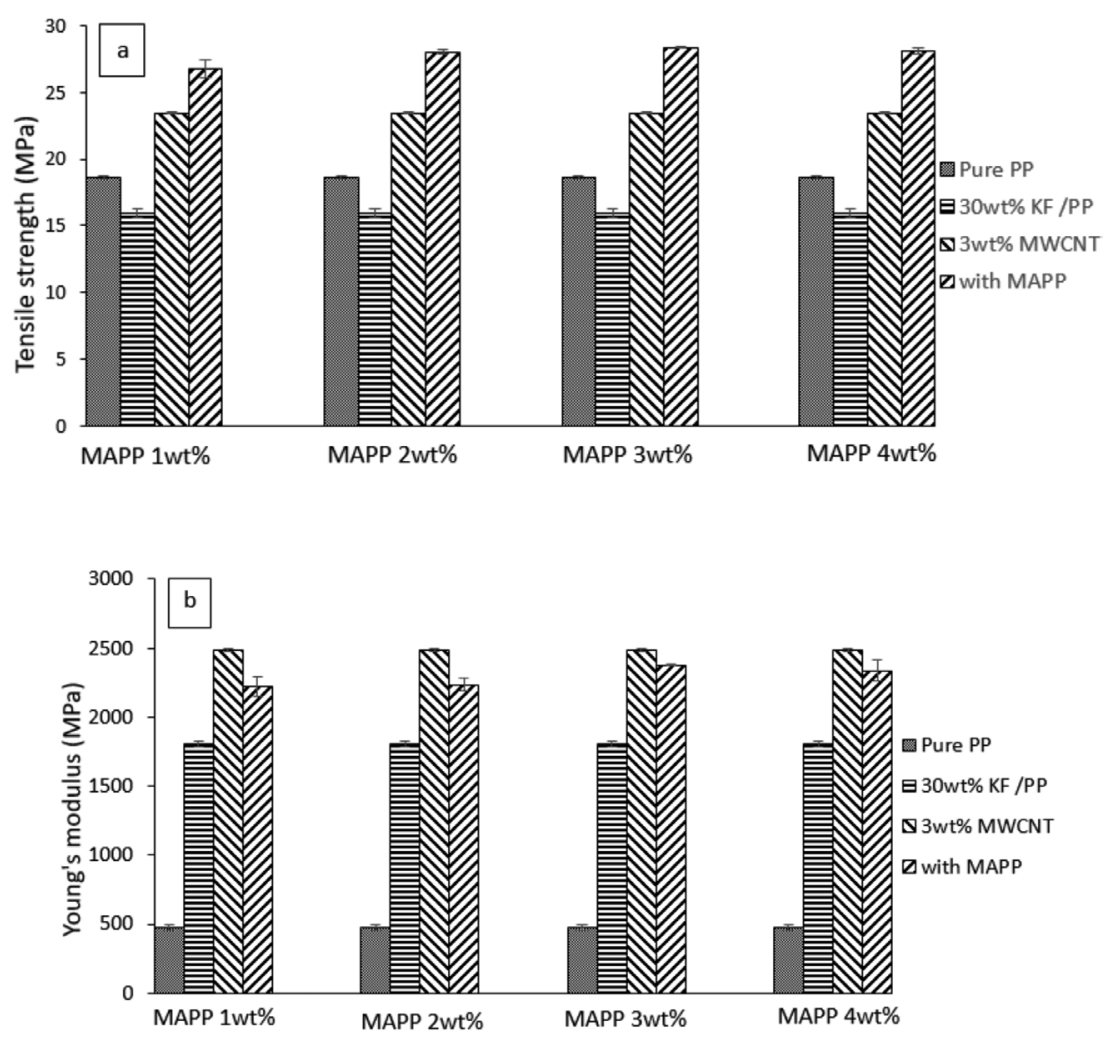

FIGURE 1. Results of MAPP effects on (a) Tensile strength of Kenaf/MWCNT /PP composite (b) Young's modulus of Kenaf/MWCNT/PP composites 

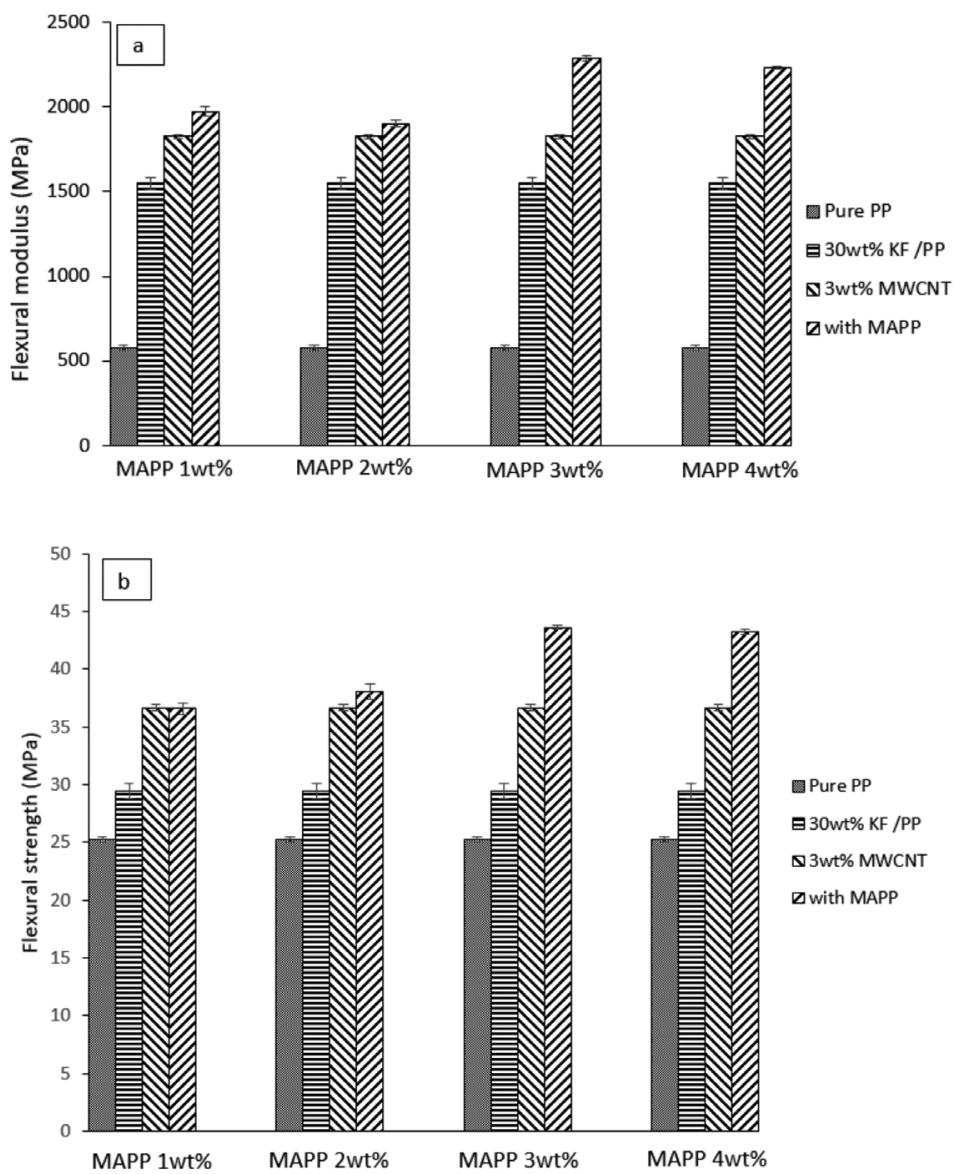

FIGURE 2. Results of MAPP effects on (a) Flexural modulus and (b) Flexural strength of Kenaf/MWCNT/PP composites

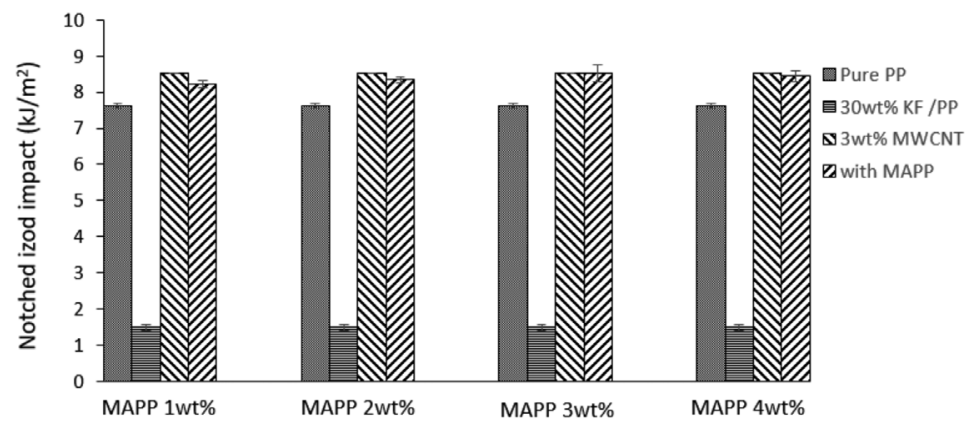

FIGURE 3. Results of impact strength caused of MAPP effects on Kenaf/MWCNT/PP composites

\section{THERMOGRAVIMETRIC ANALYSIS}

Figure 4 shows the TGA results generated on Kenaf/MWCNT/ PP and Kenaf/MWCNT/ MAPP/PP composites. The graph displays the number of sample temperatures for composites under a nitrogen purge. Nearly $7.2 \mathrm{mg}$ was heated using a TA Instruments (Model Q500). The TGA results showed that the Kenaf/MWCNT/PP undergoes thermal degradation beginning at $269.19^{\circ} \mathrm{C}$ and stopped at $363.22^{\circ} \mathrm{C}$ with a mass of $1.408 \mathrm{mg}$. This is referred to as Kenaf fibre. Initially, at $363^{\circ} \mathrm{C}$ to $570^{\circ} \mathrm{C}$, PP was degraded having a mass of 5.1 $\mathrm{mg}$. For the Kenaf/MWCNT/MAPP/PP composites undergoes thermal degradation beginning at $271.97^{\circ} \mathrm{C}$ and stopped at $367.12^{\circ} \mathrm{C}$ involving the loss of about 1.276 of the mass of the kenaf fibre and PP was degraded at $367.12^{\circ} \mathrm{C}$ to $535.08^{\circ} \mathrm{C}$ containing the loss of about $4.046 \mathrm{mg}$ of mass. The decomposition temperatures were nearly the same for all composites in the experiment, which demonstrated that the heat destruction caused to the resulting MWCNT in this review was not reliant on the content of filler.

\section{MORPHOLOGICAL CHARACTERIZATION}

Figure 5(a) and 5(b) shows the SEM images of the effect of MAPP on the tensile fracture surfaces of Kenaf/MWCNT/ 


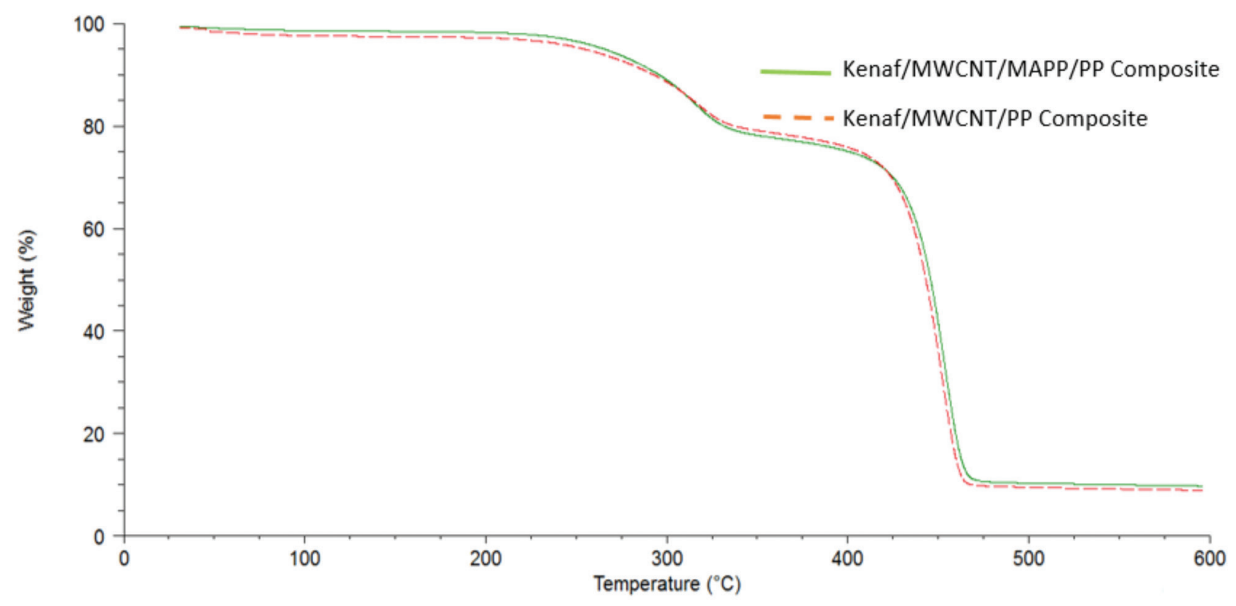

FIGURE 4. TGA results obtained for Kenaf/ MWCNT/ PP and Kenaf/MWCNT/MAPP/ PP showing thermal degradation

PP composites. The SEM images of the tensile fracture surface for composites were at MAPP 3 and 4 wt. \% loading. In Figure 5(a), the SEM image illustrates better filler dispersion of MAPP, being embedded and coated by PP matrix. Figure 5(b) shows the tensile fracture surface of MAPP on Kenaf/MWCNT/PP composites and the existence of pulled-out traces, which can be observed by the lack of interfacial adhesion occurring at the interface. The wet ability of the kenaf surface improved by adding MAPP in the composites. Figure 5(b) shows the enhanced bonding where the fibre is extracted from the matrix, with a uniform quantity of polymer residue remaining on the fibre (Ismail et al. 1997).

Figure 6(a) and 6(b) illustrates the interfacial properties of Kenaf/MWCNT/PP hybrid composites with MAPP using SEM, showing the effects of MAPP on the notched impact strength surfaces of Kenaf/MWCNT/PP composites made with different amounts of the coupling agent. Figure 6(a) indicates the existence of broken fibres appearing on the surface of the compound at MAPP $3 \mathrm{wt}$. $\%$ loading. During conditions of stress, the fibres will break due to strong adhesion existing between the fibre and matrix (Ismail et al. 1997). The notch propagation of Kenaf/MWCNT/PP on the impact measurement is a result of the high impact strength of the composites. From Figure 6(b), it can be observed that voids are also formed on the surface area of the composite indicating the reduction in the strength of the composite. The material removed increased the strength marginally as compared to the $4 \mathrm{wt}$. $\%$ loading of MAPP due to the issue associated with its wet ability problem and an increase of void fraction content.

Dispersion of MWCNT in hybrid composites were investigated for cross-section surface. Figure 7(a) shows the presence of agglomerated MWCNT. Whereas homogenously dispersed in hybrid composites which is the addition of MAPP as seen in Figure 7(b). Hence, MAPP showed the better dispersibility and interaction in the polymer matrix.

\section{CONCLUSION}

Based on the results and the discussions contained in this study the following conclusions are drawn. Increasing the coupling agent, MAPP in the Kenaf/MWCNT/PP composite will increase the tensile and flexural properties of the composite along with the impact strength increasing at MAPP 3 wt. \% loading. The research confirmed the increment of bonding occurring among the filler and the matrix polymer by adding MAPP. The SEM images illustrated that no clear gaps were appearing between
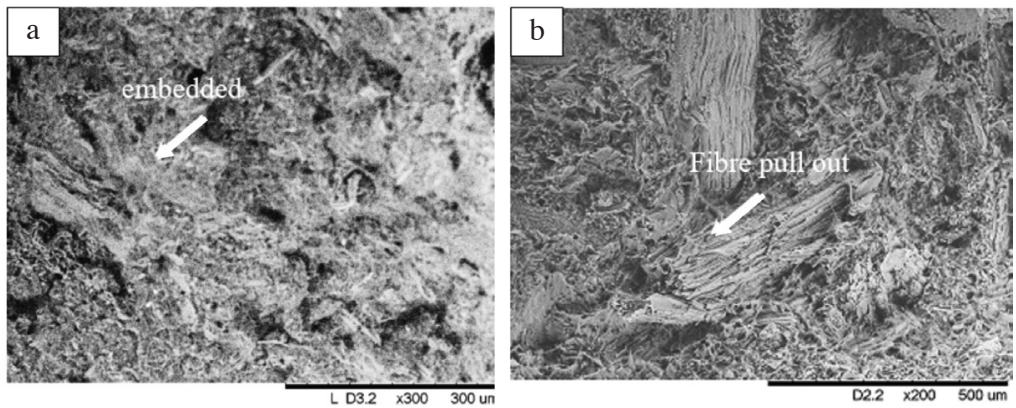

FIGURE 5. SEM results obtained for fracture surface (tensile) of MAPP on Kenaf/ MWCNT/PP composites: (a) MAPP 3 wt. $\%$ and (b) MAPP 4 wt. \% 

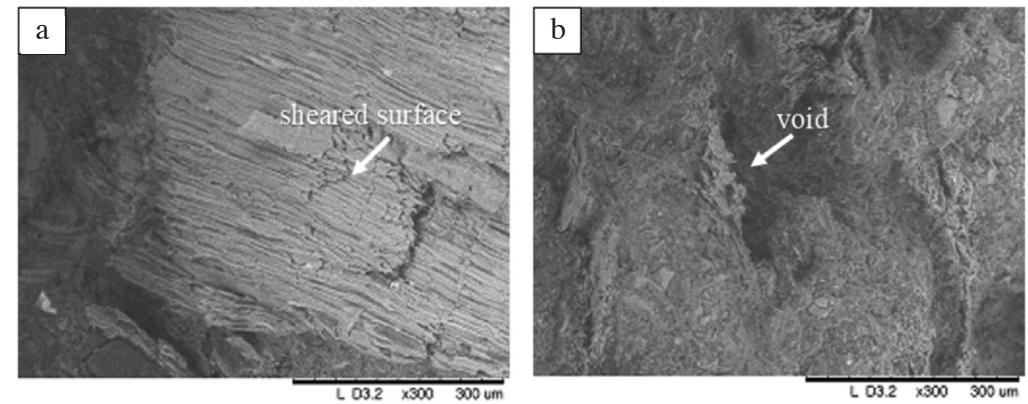

FIGURE 6. SEM results obtained from the fracture surface (impact strength) of MAPP on Kenaf/MWCNT/PP composites: (a) MAPP 3 wt. \% and (b) MAPP 4 wt. \%
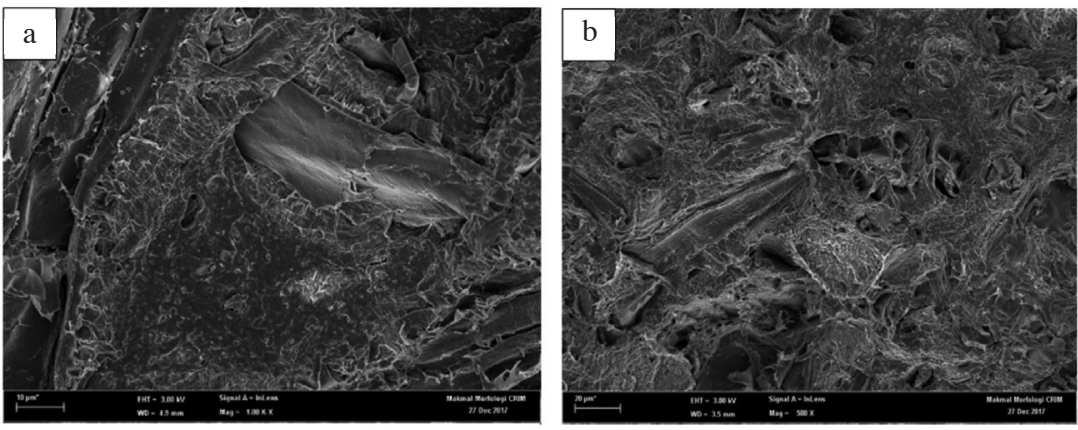

FIGURE 7. FESEM cross-section images of (a) the Kenaf/MWCNT/PP and (b) the Kenaf/MWCNT/MAPP/PP composites

the Kenaf fibres and PP matrix at MAPP 3 wt. \% loading, therefore indicating good interface bonding. In conclusion, the work performed and the results met the objective of this study.

\section{ACKNOWLEDGEMENTS}

The researchers wish to thank the Ministry of Higher Education (MOHE), Malaysia and Universiti Kebangsaan Malaysia for the financial support under grant LRGS/1/2015/ TK03/UKM/01/5.

\section{REFERENCES}

Amran, M., Izamshah, R., Hadzley, M., Shahir, M., Amri, M., Sanusi, M. \& Hilmi, H. 2014. The effect of binder on mechanical properties of kenaf fibre/polypropylene composites using full factorial method. Applied Mechanics and Materials 695: 709-712.

Edeerozey, A.M., MdAkil, H., Azhar, A.B. \& Zainal Ariffin, M.I. 2007. Chemical modification of kenaf fibers. Materials Letters 61: 2023-2025.

Eng, C.C., Ibrahim, N.A., Zainuddin, N., Ariffin, H. \& Wan Yunus, W.M.Z. 2014. Impact strength and flexural properties enhancement of methacrylate silane treated oil palm mesocarp fiber reinforced biodegradable hybrid composites. The Scientific World Journal 2014: 1-8.

Farzi, G., Akbar, S., Beyou, E., Cassagnau, P. \& Melis, F. 2009. Effect of radical grafting of tetramethylpentadecane and polypropylene on carbon nanotubes dispersibility in various solvents and polypropylene matrix. Polymer 50: 901-908.
Huseinsyah, S., Chun, K.S., Yeng, C.M. \& Ismail, A. 2016. Tensile, thermal and water absorption properties of coconut oil coupling agent. Sains Malaysiana 45(11): 1733-1739.

Iijima, S. 1991. Helical microtubules of graphitic carbon. Nature 354: 56-58.

Ismail, H., Rosnah, N. \& Rozman, H.D. 1997. Curing characteristics and mechanical properties of short oil palm fibre reinforced rubber composites. Polymer 38: 4059-4064.

Karmaker, A.C. \& Youngquist, J.A. 1996. Injection molding of polypropylene reinforced with short jute fibers. Applied Polymer Science 62: 1147-1151.

Karnani, R., Krishnan, M. \& Narayan, R. 1997. Biofiber reinforced polypropylene composites. Polymer Engineering and Science 37(2): 476-483.

Kim, K.S. \& Park, S.J. 2010. Characterization of graphene-based supercapacitors fabricated on Al foils using $\mathrm{Au}$ or Pd thin films as interlayers. Synthetic Metals 160: 2613-2617.

Lee, Y.S., Im, J.S., Yun, S.M., Nho, Y.C., Kang, P.H. \& Jin, H. 2009. X-ray photoelectron spectroscopic analysis of modified MWCNT and dynamic mechanical properties of e-beam cured epoxy resins with the MWCNT. Carbon Letter 10: 314-319.

Lu, J.Z., Wu, Q. \& Harold, S.M. 2005. Chemical coupling in wood fibre and polymer composites: A review of coupling agents and treatments. Wood and Fibre Science 32(1): 88-104.

MdRadzi, M.K.F., Sulong, A.B., Muhamad, N., MohdLatiff, M.A. \& Ismail, N.F. 2015. Effect of filler loading and $\mathrm{NaOH}$ addition on mechanical properties of moulded kenaf/ polypropylene composite. Pertanika Journal of Tropical Agricultural Science 38(4): 583-590.

Mohd Hafizzuddin, A.G., Mohd. Nazry, S., Ruey, S.S., Sohrim, A., Nishata Royan, R.R. \& Mohd. Nazri, I. 2016. Mechanical 
properties study of epoxy nanocomposite reinforced hybrid fibre carbon nanotubes and nano clay. Sains Malaysiana 45(8): 1259-1263.

Panthapulakkal, S. \& Sain, M. 2007. Injection - molded short hemp fiber/glass fiber - reinforced polypropylene hybrid composites - mechanical, water absorption and thermal properties. Journal of Applied Polymer Science 103: 24322441.

Razak, Z., Sulong, A.B., Muhamad, N., Md. Radzi, M.K.F., Tholibon, D., Tharazi, I. \& Ismail, N.F. 2016. Mechanical properties of injection moulded for multi-walled carbon nanotube/ kenaf/ polypropylene hybrid composites. Proceedings of Advanced Process and Systems in Manufacturing an International Conference. pp. 39-140.

Riley, A.M., Payneter, C.D., McGenity, P.M. \& Adams, J.M 1990. The effects of a compatibilizer on the properties of polypropylene/silica/white rice husk ash hybrid composites. Plastic and Rubber Processing and Application 14: 8593.

Rozman, H., Tay, G., Abubakar, A. \& Kumar, R. 2001. Tensile properties of oil palm empty fruit bunch-polyurethane composites. European Polymer Journal 37(9): 1759-1765.

Saad, M.J. 2011. Effect of maleated polypropylene (MAPP) on the tensile, impact and thickness swelling properties of kenaf core-polypropylene composites. Journal of Science and Technology 1: 33-44.
Schneider, J.P., Madison, K. \& Ajit, C. 1995. Composites from jute and kenaf reinforced polypropylene. ANTEC 2086.

Sharifah,H.A. \& Martin, P.A. 2004 . The effect of alkalization and fibre alignment on the mechanical and thermal properties of kenaf and hemp bast fibre composites: Part 1 - polyester resin matrix. Composites Science and Technology 64: 1219-1230.

Sharifah, H.A., Martin, P.A., Simon, J.C. \& Simon, R.P. 2005 Modified polyester resins for natural fibre composites Composites Science and Technology 65: 525-535.

Sulong, A.B. \& Park, J. 2010. Alignment of multi-walled carbon nanotubes in a polyethylene matrix by extrusion shear flow: Mechanical properties enhancement. Journal of Composite Materials 45(8): 931-941.

Department of Mechanical \& Materials Engineering

Faculty of Engineering \& Built Environment

Universiti Kebangsaan Malaysia

43600 UKM Bangi, Selangor Darul Ehsan

Malaysia

*Corresponding author; email: abubakar@ukm.edu.my

Received: 7 June 2017

Accepted: 8 February 2018 